\title{
PENERAPAN STANDAR AKUNTANSI KEUANGAN ENTITAS TANPA AKUNTABILITAS PUBLIK (SAK-ETAP) DALAM PENYAJIAN LAPORAN KEUANGAN
}

\author{
Deswati Supra \\ Dosen STIE RahmaniyahSekayu \\ Email :deswatisupra98@gmail.com
}

\begin{abstract}
Abstrak
Penelitian ini bertujuan untuk mengetahui penerapan SAK-ETAP dalam penyajian laporan keuangan CV. Sukat Perkebunan. Data yang digunakan dalam penelitian ini adalah data sekunder berupa laporan keuangan. Penelitian ini menggunakan teknik pengumpulan data dengan wawancara, studi kepustakaan, dan dokumentasi. Teknik analisis data yang digunakan adalah analisis deskriptif kualitatif. Penelitian ini menemukan bahwa CV. Sukat Perkebunan belum menerapkan dengan baik dan benar Standar Akuntansi Keuangan Entitas Tanpa Akuntabilitas Publik (SAK-ETAP).
\end{abstract}

Kata kunci : Standar Akuntansi, Laporan Keuangan, SAK ETAP.

\section{PENDAHULUAN}

\section{Latar Belakang}

Standar Akuntansi Keuangan (SAK) merupakan aturan dasar untuk menyusun laporan keuangan. Standar akuntansi keuangan dibuat sedemikian rupa sehingga informasi laporan keuangan mengenai sebuah usaha dapat dipercaya dan diperbandingkan. Standar Akuntansi Keuangan Entitas Tanpa Akuntabilitas Publik merupakan SAK-ETAP yang diperuntukan bagi entitas yang laporan keuangannya tidak akuntabel untuk publik secara luas.

CV. Sukat Perkebunan merupakan perusahaan yang bergerak dibidang supplier. Selama beraktivitas perusahaan ini tidak mempunyai permasalahan dengan pemenuhan kewajiban terhadap karyawan. Karyawan datang bahkan dari berbagai daerah, karena perusahaan CV. Sukat Perkebunan menyediakan berbagai fasilitas bagi karyawan yang memang benar-benar ingin bekerja dengan sungguhsungguh. Perlakuan status dan jabatan pada perusahaan ini, terutama disektor perkebunan, yaitu ada sebagai karyawan permanen dan karyawan outsourcing.

CV. Sukat Perkebunan menyajikan laporan keuangan yang terdiri dari laporan laba rugi dan laporan neraca. Seperti halnya entitas bisnis yang lain, CV. Sukat Perkebunan juga harus menyajikan laporan keuangan seperti Neraca, Laba 
Jurnal Ilmiah Akuntansi Rahmaniyah (JIAR)

Vol. 2 No.2, Juni 2019, 64 - 75

Supra

Rugi, Perubahan Ekuitas, Laporan Arus Kas, dan Catatan Atas Laporan Keuangan yang disusun sesuai Prinsip Akuntansi Berlaku Umum yang berlaku di Indonesia salah satunya yaitu Standar Akuntansi Keuangan Entitas Tanpa Akuntabilitas Publik (SAK-ETAP) dalam Standar Akuntansi Keuangan.

Laporan keuangan CV. Sukat Perkebunan diatas, bahwa laporan keuangan CV. Sukat Perkebunan masih belum lengkap dan belum menerapkan dengan baikdan benar Standar Akuntansi Keuangan Entitas Tanpa Akuntabilitas Publik (SAK-ETAP).Berdasarkan uraian diatas, maka penulis tertarik untuk melakukan penelitian dengan judul Penerapan Standar Akuntansi Keuangan Entitas Tanpa Akuntabilitas Publik(SAK-ETAP) dalam Penyajian Laporan Keuangan.

\section{Rumusan Masalah}

Berdasarkan latar belakang masalah yang telah diuraikan sebelumnya, Penulis merumuskan masalah: Bagaimana penerapan SAK-ETAP dalam penyajian laporan keuangan pada CV. Sukat Perkebunan.

\section{Tujuan Penelitian}

Tujuan penelitian ini adalah untuk mengetahui pererapan SAK-ETAP dalam penyajian laporan keuangan CV. Sukat Perkebunan.

\section{LANDASAN TEORI}

\section{Laporan Keuangan}

Menurut Fahmi (2012: 22), Laporan keuangan sebenarnya merupakan suatu pernyataan resmi yang harus dipertanggung jawabkan kebenarannya secara yuridis. Kesalahan atau ketidak jujuran dalam penyajian membawa konsekuensi yuridis bagi penyaji. Apa yang termuat dalam laporan keuangan dapat dijadikan basis untuk menuntut penyaji oleh pihak yang merasa dirugikan karena mempercayai dan menggunakan laporan tersebut. Seperangkat laporan keuangan umum yang lengkap biasanya terdiri dari Laporan Neraca, Laporan Arus Kas, Laporan laba Rugi, Laporan Perubahan Modal dan Catatan Atas Laporan Keuangan. 
Jurnal Ilmiah Akuntansi Rahmaniyah (JIAR)

Vol. 2 No.2, Juni 2019, 64 - 75

Supra

\section{Definisi SAK-ETAP}

Standar Akuntansi Keuangan Entitas tanpa Akuntabilitas Publik (SAKETAP) merupakan standar akuntansi yang digunakan oleh entitas yang menyusun laporan keuangan. Entitas yang dimaksud dalam SAK-ETAP adalah entitas tanpa akuntabilitas yaitu:

1. Tidak memiliki akuntabilitas publik signifikan

2. Menerbitkan laporan keuangan untuk tujuan umum (general purpose finacial statement) bagi pengguna eksternal.

\section{Tujuan Penyusunan SAK-ETAP}

Perusahaan dapat menggunakan SAK-ETAP dikarenakan:

1. PSAK IFRS sulit diterapkan bagi perusahaan kecil menengah mengingat penentuan fair value memerlukan biaya yang tidak sedikit.

2. PSAK IFRS rumit dalam implementasinya.

3. PSAK IFRS menggunakan principle based sehingga membutuhkan banyak professional judgement.

4. PSAK IFRS perlu dokumentasi dan efisiensi yang kuat.

\section{Penyajian dan Pelaporan Laporan Keuangan Menurut SAK-ETAP}

Dasar pengukuran laporan keuangan menurut SAK-ETAP adalah biaya historis dan nilai wajar, untuk komponen laporan keuangannya meliputi laporan neraca, laporan laba rugi, laporan perubahan ekuitas, laporan arus kas, dan catatan atas laporan keuangan. Biaya historis adalah kas atau setara kas yang dibayarkan untuk memperoleh aset pada saat perolehan. Laporan posisi keuangan dihasilkan dari suatu periode tertentu yang menunjukan posisi keuangan perusahaan pada akhir periode akuntansi. Laporan laba rugi memberikan informasi mengenai hubungan antara beban dan penghasilan dari suatu entitas. Laporan keuangan menurut SAK-ETAP memang ditunjukan untuk usaha kecil menengah, namun juga tidak menutup kemungkinan untuk pengusaha UKM yang belum memahami konsepnya. Apabila SAK-ETAP sudah berjalan efektif, UKM tidak perlu membuat laporan keuangan menggunakan PSAK umum yang lebih sulit dan kompleks dari SAK-ETAP. 
Jurnal Ilmiah Akuntansi Rahmaniyah (JIAR)

Vol. 2 No.2, Juni 2019, 64 - 75

Supra

\section{Kerangka pemikiran}

Berdasarkan uraian yang telah dikemukakan, maka dapat digambarkan paradigma penelitian sebagai berikut:

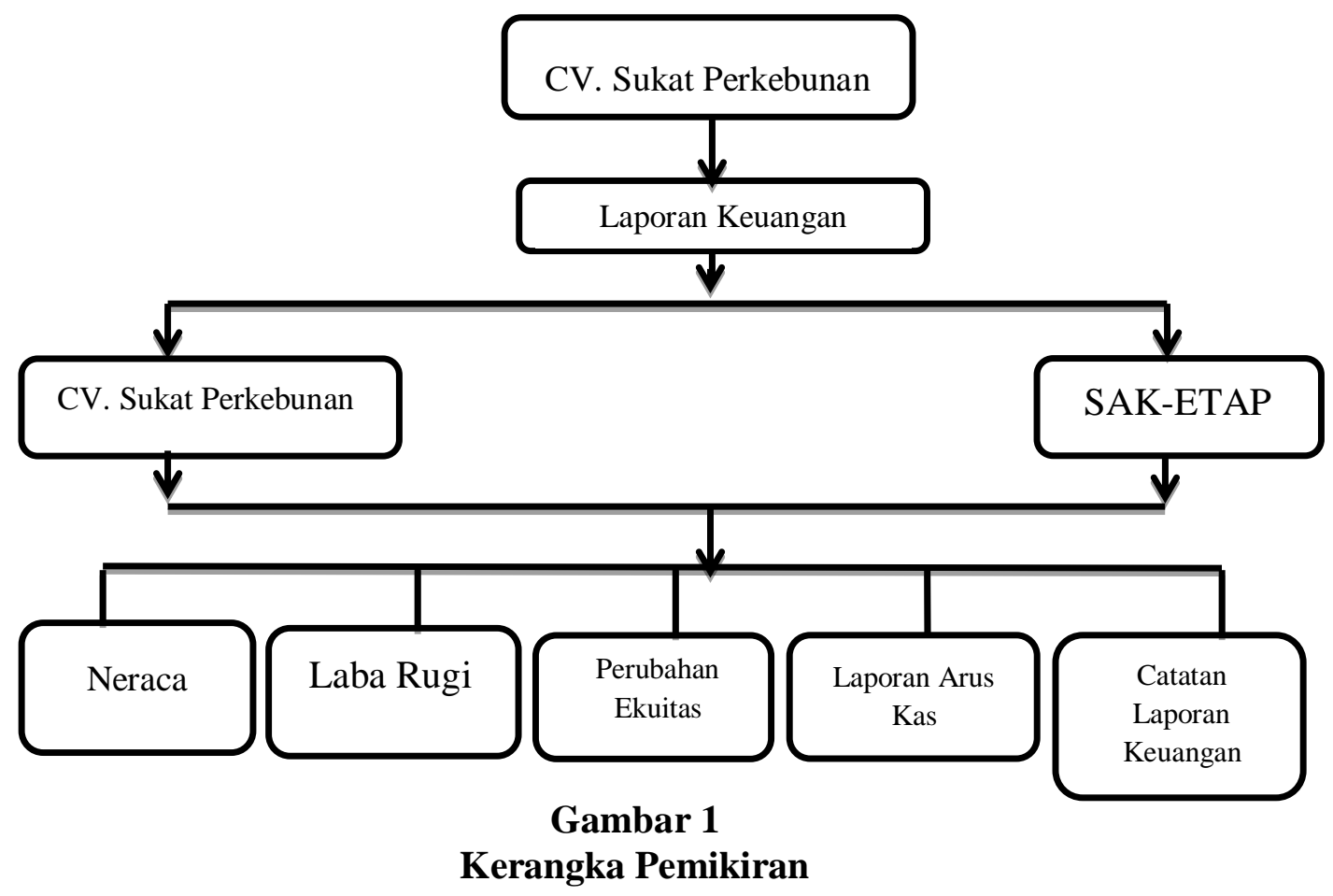

Berdasarkan Kerangka pemikiran diatas, penulis menganalisis penerapan

SAK ETAP dalam penyajian Laporan Keuangan Perusahaan CV. Sukat Perkebunan.

\section{METODOLOGI PENELITIAN}

\section{Lokasi dan Waktu Penelitian}

Untuk memperoleh data dalam penelitian ini, penulis melakukan penelitian pada CV. Sukat Perkebunan yang beralamat di Desa Bandar Jaya Kecamatan Sekayu. Dengan waktu penelitian yang dilaksanakan dari Bulan Januari sampai Bulan Mei 2019.

\section{Jenis dan Sumber Data}

Sugiyono (2013: 56), dilihat dari sumber yang digunakan pada penelitian data dapat dibagi menjadi data primer dan data data sekunder. Pada penelitian ini data yang digunakan adalah: 


\section{Data Primer}

Data Primer merupakan data yang langsung penulis peroleh dari objek penelitian dengan cara mengumpulkan serta mempelajari data yang berasal dari CV. Sukat Perkebunan.

2. Data Sekunder

Data Sekunder dalam penelitian ini berupa data jumlah karyawan perusahaan dan struktur perusahaan CV. Sukat Perkebunan.

\section{Teknik Pengumpulan Data}

Sugiyono (2013: 63), data merupakan faktor penting dalam penelitian, untuk itu diperlukan teknik tertentu dalam pengumpulan data. Metode yang akan diterapkan dalam pengumpulan data dalam penelitian ini adalah:

1. Wawancara

2. Dokumentasi

3. Studi Kepustakaan

\section{Teknik Analisis Data}

Proses analisis data secara keseluruhan melibatkan usaha memaknai data yang berupa teks atau gambar. Sugiyono (2013: 68), mendefinisikan analisis data adalah proses mencari dan menyusun secara sistematis data yang diperoleh dari hasil wawancara, catatan lapangan, dan bahan-bahan lain sehingga dapat mudah dipahami dan temuannya dapat diinformasikan kepada semua pihak. Peneliti mengunakan teknik analisis data deskriptif kualitatif karena teknik deskriptif kualitatif menggunakan kata-kata yang selalu disusun dalam sebuah teks yang diperluaskan atau dideskripsikan.

\section{HASIL DAN PEMBAHASAN}

Pembahasan dimaksudkan untuk menganalisis data laporan keuangan menggunakan Standar Akuntansi Keuangan Entitas Tanpa Akuntabilitas Publik (SAK-ETAP) dan teori yang ada untuk menyajikan laporan keuangan berdasarkan Standar Akuntansi Keuangan Entitas Tanpa Akuntabilitas Publik (SAK-ETAP). 


\section{Laporan Laba Rugi}

Berikut ini adalah laporan laba rugi yang disusun oleh CV. Sukat Perkebunan.

\section{Tabel 1}

CV. Sukat Perkebunan

Laporan Laba Rugi

Untuk Periode yang Berakhir pada 31 Desember 2017 dan 2018

\begin{tabular}{|c|c|c|c|c|}
\hline \multirow{2}{*}{\begin{tabular}{l}
\multicolumn{1}{c}{ Keterangan } \\
Pendapatan Penjualan \\
Penjualan
\end{tabular}} & \multicolumn{2}{|c|}{ Tahun 2017} & \multicolumn{2}{|c|}{ Tahun 2018} \\
\hline & & 970.000 .000 & & 1.220 .000 .000 \\
\hline \multicolumn{5}{|l|}{ HPP } \\
\hline Persediaan Awal & 655.000 .000 & & 710.655 .000 & \\
\hline Pembeliaan & 395.700 .000 & & 423.115 .000 & \\
\hline Return Pembelian & 0 & & 0 & \\
\hline Pembeliaan Bersih & 395.700 .000 & & 423.115 .000 & \\
\hline Barang Siap Dijual & 1.050 .700 .000 & & 1.133 .770 .000 & \\
\hline Persediaan Akhir & $(259.300 .000)$ & & $(287.540 .000)$ & \\
\hline Нpp & \multicolumn{2}{|r|}{791.400 .000} & & 846.230 .000 \\
\hline Laba Kotor Penjualan & & 178.600 .000 & & 373.770 .000 \\
\hline \multicolumn{5}{|l|}{ Pendapatan Sewa } \\
\hline Pendapatan Sewa Mobil & 135.700 .000 & & 192.500 .000 & \\
\hline Pendapatan Sewa Alat Berat & 390.000 .000 & & 435.000 .000 & \\
\hline Pendapatan Lain-lain & 55.000 .000 & & 72.000 .000 & \\
\hline Total Pendapatan Sewa & & 580.700 .000 & & 699.500 .000 \\
\hline Laba Sebelum Biaya & & 759.300 .000 & & $\overline{1.073 .270 .000}$ \\
\hline \multicolumn{5}{|l|}{ Biaya-biaya } \\
\hline Biaya Listrik & 14.000 .000 & & 38.400 .000 & \\
\hline Biaya Air & 6.100 .000 & & 8.200 .000 & \\
\hline Biaya Perlengkapan & 9.500 .000 & & 15.000 .000 & \\
\hline Biaya Gaji & 225.700 .000 & & 292.800 .000 & \\
\hline Biaya Telepon & 4.300 .000 & & 6.500 .000 & \\
\hline Biaya BBM & 14.050 .000 & & 15.100 .000 & \\
\hline Biaya Peny. Peralatan & 3.200 .000 & & 3.200 .000 & \\
\hline Biaya Peny. Gedung & 21.000 .000 & & 21.000 .000 & \\
\hline Biaya Peny. Kendaraan & 31.500 .000 & & 31.500 .000 & \\
\hline Biaya Perawatan Kendaraan & 30.000 .000 & & 36.300 .000 & \\
\hline Biaya Pajak & 38.735 .000 & & 47.175 .000 & \\
\hline Biaya Lain-lain & $\underline{16.000 .000}$ & & 21.000 .000 & \\
\hline Jumlah Biaya & & $(414.085 .000)$ & & $(536.175 .000)$ \\
\hline Laba Setelah Pajak & & 345.215.000 & & 537.095 .000 \\
\hline
\end{tabular}

Sumber: CV. Sukat Perkebunan tahun 2019, data diolah

Berdasarkan Tabel 1, Laporan laba rugi CV. Sukat Perkebunan terlihat bahwa pengklasifikasian dan penyajian pendapatan usaha, beban usaha, pendapatan, pajak dan beban lain-lain. Dampak dalam penyajian laporan laba rugi 
Jurnal Ilmiah Akuntansi Rahmaniyah (JIAR)

Vol. 2 No.2, Juni 2019, 64 - 75

Supra

yang tidak mengungkapkan pendapatan (beban) usaha, pendapatan (beban) lainlain diluar usaha serta pajak dimasukan didalam beban yaitu jumlah laba terlihat lebih kecil dari yang sebenarnya, dengan laba terlihat lebih kecil maka dapat menimbulkan pengguna laporan keuangan terutama kreditur perusahaan dalam hal ini adalah bank dapat mengambil kesimpulan bahwa perusahaan sulit untuk berkembang atau mengurangi kepercayaan para kreditur terhadap kinerja perusahaan.

Tabel 2menyajikan laporan laba rugi CV. Sukat Perkebunan berdasarkan SAK-ETAP:

Tabel 2

CV. Sukat Perkebunan

Laporan Laba Rugi (Setelah Penerapan SAK-ETAP)

Untuk Periode yang Berakhir pada 31 Desember 2017 dan 2018

\begin{tabular}{|c|c|c|}
\hline Keterangan & 2017 & 2018 \\
\hline Pendapatan Usaha: & & \\
\hline Penjualan & 970.000.000 & 1.220 .000 .000 \\
\hline Harga Pokok Penjualan & (791.400.000) & $(846.230 .000)$ \\
\hline Laba Kotor & 178.600 .000 & 373.770.000 \\
\hline Beban Penjualan: & & \\
\hline Beban Bbm & 14.050 .000 & 15.100 .000 \\
\hline Beban Perawatan Kendaraan & $\underline{30.000 .000}$ & $\underline{36.300 .000}$ \\
\hline Total Beban Penjualan & 44.050.000 & $\overline{51.400 .000}$ \\
\hline Beban Adm dan Umum: & & \\
\hline Beban Listrik & 14.000 .000 & 38.400 .000 \\
\hline Beban Air & 6.100 .000 & 8.200 .000 \\
\hline Beban Perlengkapan & 9.500 .000 & 15.000 .000 \\
\hline Beban Gaji & 225.700 .000 & 292.800 .000 \\
\hline Beban Telepon & 4.300 .000 & 6.500 .000 \\
\hline Beban Peny. Peralatan & 3.200 .000 & 3.200 .000 \\
\hline Beban Peny. Kendaraan & 31.500 .000 & 31.500 .000 \\
\hline Beban Peny. Bangunan & $\underline{21.000 .000}$ & $\underline{21.000 .000}$ \\
\hline Total Beban Adm \& umum & $\overline{315.300 .000}$ & $4 \overline{16.600 .000}$ \\
\hline Laba Usaha & $(\overline{\mathbf{1 8 0 . 7 5 0 . 0 0 0})}$ & $\overline{(94.230 .000)}$ \\
\hline Pendapata (Beban) Lain-lain: & & \\
\hline Pendapatan Sewa Mobil & 135.700 .000 & 192.500 .000 \\
\hline Pendapatan Sewa Alat Berat & 390.000 .000 & 435.000 .000 \\
\hline Pendapatan Lain-lain & 55.000 .000 & 72.000 .000 \\
\hline Beban Lain-lain & $(16.000 .000)$ & $(21.000 .000)$ \\
\hline Total Pendapatan Lain-lain & 564.700 .000 & 678.500 .000 \\
\hline Laba Bersih Sebelum Pajak & 383.950 .000 & 584.270 .000 \\
\hline Beban Pajak: & & \\
\hline Pajak Pph Badan & 9.700 .000 & 12.200 .000 \\
\hline Pajak Pph 23 & 29.035 .000 & $\underline{34.975 .000}$ \\
\hline Total Pajak & $\overline{\mathbf{3 8 . 7 3 5 . 0 0 0}}$ & $\overline{47.175 .000}$ \\
\hline Laba Bersih Setelah Pajak & $3 \overline{45.215 .000}$ & $5 \overline{37.095 .000}$ \\
\hline
\end{tabular}


Sumber: CV. Sukat Perkebunan 2019, data diolah.

Berdasarkan laporan laba rugi diatas pada Tabel 2 adalah laporan laba rugi berdasarkan SAK-ETAP, Sedangkan laporan laba rugi yang disajikan CV. Sukat Perkebunan masih belum lengkap dan belum menerapkan dengan baik dan benar Standar Akuntansi Keuangan Entitas Tanpa Akuntabilitas Publik (SAK-ETAP)

2. Laporan Neraca

Dalam Standar Akuntansi Keuangan Entitas Tanpa Akuntabilitas Publik (2018: 20), Neraca menyajikan aset, kewajiban dan ekuitas suatu entitas pada suatu tanggal tertentu akhir periode pelaporan.Berikut adalah laporan keuangan neraca yang disusun oleh CV. Sukat Perkebunan.

Tabel 3

CV. Sukat Perkebunan

Laporan Neraca

Per 31 Desember 2017 dan 2018

\begin{tabular}{|l|r|r|}
\hline \multicolumn{1}{|c|}{ Keterangan } & $\mathbf{2 0 1 7}$ & \multicolumn{1}{c|}{$\mathbf{2 0 1 8}$} \\
\hline Aktiva & 30.000 .000 & 35.000 .000 \\
Kas & 32.200 .000 & 41.633 .000 \\
Piutang Usaha & 12.000 .000 & 15.300 .000 \\
Piutang Karyawan & 1.050 .700 .000 & 1.133 .770 .000 \\
Persediaan Barang Dagang & 16.000 .000 & 16.000 .000 \\
Peralatan & $(6.400 .000)$ & $(9.600 .000)$ \\
Akum. Penyusutan peralatan & 315.000 .000 & 315.000 .000 \\
Kendaraan & $(94.500 .000)$ & $(126.000 .000)$ \\
Akum. Penyusutan Kendaraan & 420.000 .000 & 420.000 .000 \\
Bangunan & $(147.175 .000)$ & $(168.200 .000)$ \\
Akum. Penyusutan Bangunan & & \\
\hline & $\mathbf{1 . 6 2 7 . 8 2 5 . 0 0 0}$ & $\mathbf{1 . 6 7 3 . 1 0 3 . 0 0 0}$ \\
Total Aktiva & & 17.300 .000 \\
\hline PASSIVA & & 492.300 .000 \\
Hutang Gaji & 18.000 .000 & 1.163 .303 .000 \\
\hline Hutang Usaha & 420.000 .000 & $\mathbf{1 . 6 7 3 . 1 0 3 . 0 0 0}$ \\
Modal & 1.189 .825 .000 & \\
\hline Total Passiva & $\mathbf{1 . 6 2 7 . 8 2 5 . 0 0 0}$ & \\
\hline
\end{tabular}

Sumber: CV. Sukat Perkebunan tahun 2019, data diolah

Berdasarkan Tabel 3, dapat disimpulkan bahwa laporan neraca yang disajikan CV. Sukat Perkebunan belum sesuai dengan SAK-ETAP, belum adanya pengklasifikasian dalam menyajikan aset lancar dengan aset tidak lancar, kewajiban lancar dengan kewajiban tidak lancar dan kewajiban dengan modal sehingga jumlah aset lancar, aset tidak lancar, kewajiban lancar, kewajiban tidak lancar dan ekuitas tidak diungkapkan dengan baik. Penyajian neraca yang belum 
Jurnal Ilmiah Akuntansi Rahmaniyah (JIAR)

Vol. 2 No.2, Juni 2019, 64 - 75

Supra

adanya pengklasifikasian dalam menyajikan aset lancar dan aset tidak lancar, kewajiban lancar dengan kewajiban tidak lancar dan kewajiban dengan modal yaitu laporan keuangan neraca menjadi sulit dipahami oleh pengguna laporan keuangan dan tidak dapat diperbandingkan guna pihak manajemen perusahaan untuk mengambil keputusan maupun pengguna laporan keuangan lainnya untuk mengevaluasi kinerja perusahaan.Tabel 4 menyajikan laporan neraca CV. Sukat Perkebunan berdasarkan SAK-ETAP:

Tabel 4

CV. Sukat Perkebunan

Neraca (Sesudah Penerapan SAK-ETAP)

Per 31 Desember 2017 dan 2018

\begin{tabular}{|c|c|c|}
\hline Keterangan & 2017 & 2018 \\
\hline \multicolumn{3}{|l|}{ Aset } \\
\hline Aset Lancar: & & \\
\hline Kas & 30.000 .000 & 35.000 .000 \\
\hline Piutang Usaha & 32.200 .000 & 41.633 .000 \\
\hline Piutang Lain-lain & 12.000 .000 & 15.300 .000 \\
\hline Persediaan & 1.050 .700 .000 & 1.133 .770 .000 \\
\hline Biaya Dibayar Dimuka & 0 & 0 \\
\hline Jumlah Aset Lancar & 1.124 .900 .000 & 1.225.703.000 \\
\hline \multicolumn{3}{|l|}{ Aset Tidak Lancar: } \\
\hline Peralatan & 16.000 .000 & 16.000 .000 \\
\hline Akumulasi Penyusutan Peralatan & $(6.400 .000)$ & $(9.600 .000)$ \\
\hline Kendaraan & 315.000 .000 & 315.000 .000 \\
\hline Akumulasi Penyusutan Kendaraan & $(94.500 .000)$ & $(126.000 .000)$ \\
\hline Bangunan & 420.000 .000 & 420.000 .000 \\
\hline Akumulasi Penyusutan Bangunan & $(147.175 .000)$ & $(168.000 .000)$ \\
\hline Investasi & 0 & 0 \\
\hline Aset Tidak Lancar Lainnya & 0 & 0 \\
\hline Jumlah Aset Tidak Lancar & $\mathbf{5 0 2 . 9 2 5 . 0 0 0}$ & 447.400 .000 \\
\hline Jumlah Aset & $\overline{1.627 .825 .000}$ & $\overline{1.673 .103 .000}$ \\
\hline \multicolumn{3}{|l|}{ Kewajiban } \\
\hline \multicolumn{3}{|l|}{ Kewajiban Lancar: } \\
\hline Hutang Usaha & 420.000 .000 & 492.300 .000 \\
\hline Kewajiban Lancar Lainnya & 18.000 .000 & 17.300 .000 \\
\hline Hutang Sewa & 0 & 0 \\
\hline Hutang Bank & 0 & 0 \\
\hline Jumlah Kewajiban Lancar & 438.000 .000 & 509.600 .000 \\
\hline \multicolumn{3}{|l|}{ Kewajiban Tidak Lancar: } \\
\hline Hutang Bank Jangka Panjang & 0 & 0 \\
\hline Kewajiban Tidak Lancar Lainnya & 0 & 0 \\
\hline Jumlah Kewajiban Tidak Lancar & 0 & 0 \\
\hline Jumlah Kewajiban & 438.000.000 & $\mathbf{5 0 9 . 6 0 0 . 0 0 0}$ \\
\hline \multicolumn{3}{|l|}{ Ekuitas } \\
\hline Modal & 1.189 .825 .000 & 1.163 .503 .000 \\
\hline Jumlah Ekuitas & 1.189 .825 .000 & $\underline{1.163 .503 .000}$ \\
\hline Jumlah Kewajiban dan Ekuitas & 1.627 .825 .000 & 1.673 .103 .000 \\
\hline
\end{tabular}

Sumber: CV. Sukat Perkebunan 2019, data diolah 
3. Laporan Perubahan Ekuitas

Dalam Standar Akuntansi Keuangan Entitas Tanpa Akuntabilitas Publik (2018: 26), laporan perubahan ekuitas menyajikan laba atau rugi entitas untuk suatu periode, pos pendapatan, dan beban yang diakui secara langsung dalam ekuitas untuk periode tersebut. Informasi yang disajikan dalam laporan perubahan ekuitas adalah:

a) Laba atau rugi untuk periode berjalan.

b) Pendapatan dan beban yang diakui langsung dalam ekuitas.

c) Untuk setiap komponen ekuitas, suatu rekonsiliasi antara jumlah tercatat awal dan akhir periode.

Berdasarkan data yang diperoleh, CV. Sukat Perkebunan belum menyajikan laporan perubahan ekuitas dalam laporan keuangannya, sehingga informasi akun-akunnya tidak bisa digambarkan secara rinci.

4. Laporan Arus Kas

Laporan arus kas menyajikan informasi perubahan historis atas kas dan setara kas entitas yang menunjukan secara terpisah perubahan yang terjadi selama satu periode dari aktivitas operasi, investasi dan pendanaan. Informasi yang disajikan dalam arus kas adalah:

a. Aktivitas Operasi, arus kas dari aktivitas operasi terutama diperoleh dari aktivitas penghasilan utama pendapatan entitas. Contoh: penerimaan kas dari penjualan barang dan jasa, penerimaan kas dari royalti, fees, komisi dan pendapatan lain, pembayaran kas kepada pemasok dan lain-lain.

b. Aktivitas Investasi, arus kas dari aktivitas investasi mencerminkan pengeluaran kas sehubungan dengan sumber daya yang bertujuan untuk menghasilkan pendapatan dan arus kas masa depan. Contoh: pembayaran kas untuk memperoleh aset tetap, aset tidak berwujud dan aset lainnya. Pembayaran kas untuk memperoleh efek ekuitas atau efek utang entitas lain dan bunga dalam joint ventute selain pembayaran untuk efek yang diklasifikasikan sebagai kas atau setara kas atau dimiliki untuk diperdagangkan dan lain-lain.

c. Aktivitas Pendanaan, contohnya adalah penerimaan kas dari penerbitan saham atau efek ekuitas lain, pembayaran kas kepada pemegang saham untuk menarik atau menebus saham ekuitas dan lain-lain. 
Jurnal Ilmiah Akuntansi Rahmaniyah (JIAR)

Vol. 2 No.2, Juni 2019, $64-75$

Supra

Berdasarkan data yang diperoleh, CV. Sukat Perkebunan belum menyajikan laporan arus kas dalam laporan keuangan mereka sehingga informasi perubahan historis atas kas dan setara kas tidak disajikan.

5. Catatan Atas Laporan Keuangan

Dalam Standar Akuntansi Keuangan Entitas Tanpa Akuntabilitas Publik (2011: 27), catatan atas laporan keuangan berisikan informasi sebagai tambahan informasi yang disajikan dalam laporan keuangan. Catatan atas laporan keuangan berisikan penjelasan naratif atau rincian jumlah yang disajikan dalam laporan keuangan dan informasi pos-pos yang tidak memenuhi kriteria pengakuan dalam laporan keuangan.Berdasarkan informasi yang diperoleh, CV. Sukat Perkebunan tidak membuat catatan atas laporan keuangan, sehingga tidak bisa menggambarkan secara rinci mengenai akun-akun yang ada dalam laporan keuangannya.

\section{SIMPULAN}

Berdasarkan hasil analisa yang dilakukan, maka dapat disimpulkan bahwa CV. Sukat Perkebunan belum menerapkan dengan baik dan benar Standar Akuntansi Keuangan Entitas Tanpa Akuntabilitas Publik (SAK-ETAP), dan CV. Sukat Perkebunan belum menyusun atau menyajikan tiga jenis laporan keuangan lainnya yaitu: laporan perubahan ekuitas, laporan arus kas dan catatan atas laporan keuangan yang berdampak tidak dapat disajikan informasi saldo awal maupun saldo akhir modal periode berjalan dan informasi perubahan historis atas kas atau setara kas serta tidak adanya gambaran secara rinci mengenai akun-akun yang ada dalam laporan keuangan.

\section{DAFTAR PUSTAKA}

Belkaoui, Ahmed Riahi. 2012. Accounting Theory: Teori Akuntansi. Jakarta: Salemba Empat

Donald E, Kieso. 2012. Pengantar Akuntansi. Jakarta: Salemba Empat

Gill, James o dan Chatton Moira. 2012. Memahami Laporan Keuangan. Jakarta: PPM

Harahap, Sofyan. 2013.Analisis Laporan Keuangan.Jakarta: Bumi Aksara 
Jurnal Ilmiah Akuntansi Rahmaniyah (JIAR)

Vol. 2 No.2, Juni 2019, $64-75$

Supra

Irham, Fahmi. 2015. Pengantar Manajemen Keuangan. Bandung: Alfabeta

Martani, Dwi. 2012. Akuntansi Keuangan Menengah Berbasis PSAK. Jakarta: Salemba Empat

Pernyataan Standar Akuntansi Keuangan (PSAK). 2015. Pernyataan Dan Karakteristik Laporan Keuangan. Jakarta: Salemba Empat

Soemarso, S.R. 2012. Akuntansi Suatu Pengantar. Jakarta: Salemba Empat

Sugiyono. 2012. Metode Penelitian. Bandung: Alfabeta

Standar Akuntansi Keuangan Entitas Tanpa Akuntabilitas Publik (SAK-ETAP). 2018. Analisis Penyajian Laporan Keuangan. Jakarta: Ikatan Akuntan Indonesia 